\title{
Assessing the East Bay of Galveston Bay, Texas for Coliform Bacteria in Recreational Water
}

\author{
Tommy Quach, Luis Colon, Akintayo Akinrinlola, Jesse Bell, Sonya Good \\ Department of Chemistry, Texas Southern University, Houston, TX, USA \\ Email: goodsl@tsu.edu
}

How to cite this paper: Quach, T., Colon, L., Akinrinlola, A., Bell, J. and Good, S. (2016) Assessing the East Bay of Galveston Bay, Texas for Coliform Bacteria in Recreational Water. Open Journal of Marine Science, 6, 472-481.

http://dx.doi.org/10.4236/ojms.2016.64039

Received: August 28, 2016

Accepted: September 26, 2016

Published: September 29, 2016

Copyright $\odot 2016$ by authors and Scientific Research Publishing Inc. This work is licensed under the Creative Commons Attribution International License (CC BY 4.0).

http://creativecommons.org/licenses/by/4.0/

\begin{abstract}
The Galveston Bay beach is a widely used recreational area that remains a concern in terms of water quality. There are many factors that contribute to its pollution such as fecal matter entering the bay due to overflow of the sewage system and run offs. Thus, evaluating the water quality for fecal matter and other pollutants is continuously monitored by citizen scientists and research groups throughout the Galveston Bay. The investigation utilizes the colorimetric response of coliform at three test sites along the East Bay of Galveston. Each response is positive for coliform that may indicate the presence of fecal matter. Other scientists have denoted the presence of fecal matter in the Galveston Bay at two sites using enterococci indicator which may be more associated with human fecal matter. The analyses show that the recreational water is likely not a threat since its levels were low. However, the need for analyses based on EPA protocols and standards is necessary to better access water pollution due to fecal matter in the Galveston Bay area.
\end{abstract}

\section{Keywords}

Coliform Bacteria, Fecal Matter, Bacterial Indicators, Galveston Bay, Enterococci

\section{Introduction}

The primary recreational beaches of Galveston Bay have been of concern due to the positive testing of bacteria that are linked to the presence of fecal matter. Several advisories were issued by the Galveston County Health Department indicating that seventeen beaches have an elevated level of bacterial indicators associated with fecal matter when testing water in late June 2015 [1] [2]. Health officials suggest that fecal bacteria tend to be higher after heavy rain or flooding due to the overflow of sewage systems and runoffs [3]. The water was retested later the same day, which indicated only three 
of the seventeen beaches remained elevated. Such advisories and reports concern the public who utilize these beaches on a frequent basis. It is necessary to monitor the Galveston Bay for fecal coliform at several sites on a regular basis to advise the public and address water pollution. There are several monitoring groups in Texas that test the quality of water around the Galveston Bay area on a regular basis. Some of these monitoring sites are not tested for fecal bacteria. In addition, some data are not accessible online which shows changes in coliform levels from month to month and some monitoring groups do not use the same methods as specified by EPA or The Texas Commission on Environmental Quality (TCEQ).

One way to identify the presence of fecal matter in large bodies of water is to detect fecal coliform bacteria. The bacteria naturally exist in the digestive system within the digestive tract [4]. It's rare to find the presence of the fecal coliform bacteria in normal drinking water or pool water [5]. However, it's more likely to be found in bodies of water due to contamination spill, heavy flooding, illegal pollution from civilians, or sewage contamination. The Galveston Bay is used for recreational and economic purposes which lead to contamination from urban development, surface runoff, waste discharges, and shipping [6]. Pollution from these sources is the reason for concern with fecal matter in water near the beaches. Coliform bacteria may not necessarily be a harmful pathogen; however, its presence in high levels around $200 \mathrm{cfu} / 100 \mathrm{~mL}$ may indicate fecal contamination of the water body requiring additional testing with Enterococci and Escherichia coli (E. coli) to confirm [7]. The determination of enterococci as opposed fecal coliform to determine the presence of fecal matter gained popularity around 2002. The enterococci are linked closely to human fecal matter as oppose to animals. In addition, it survives longer in marine environments than coliform bacteria when detecting fecal matter days after rain or flood [8].

The importance of monitoring the Galveston Bay water is to prevent exposure or contact with fecal matter in the water which could result in pathogenic diseases such as typhoid fever, viral and bacterial gastroenteritis, and hepatitis A. According to the Morbidity and Mortality Weekly Report, there were three outbreaks of $E$. coli, seventeen cases and eight hospitalizations which occurred from 2009-2010 from untreated recreational water within the United States [9]. Although, the number of outbreaks reported is relatively low nationally, it could be problematic in the Galveston Bay area due to frequent flooding after heavy rain and sewage overflow that reduces water quality. In addition, other regions in Texas near Galveston Bay tributaries contribute to its pollution by sewage overflow from outdated sewage systems that runoff into the Galveston Bay after heavy flooding [3]. Thus, it is important to gather data regularly to monitor the toxicity levels of fecal matter to prevent water-associate disease outbreaks and protect the seafood quality in the Galveston Bay. The quality of water in the Galveston Bay can be improved by updating sewage systems of nearby regions, treating water before entering tributaries, and exposure to sunlight.

The investigation of the Galveston Bay water along the East Bay beaches consists of testing the levels of coliform bacteria using coliform indicators to confirm its presence 
and determine if further testing is needed to confirm fecal contamination. Additional analyses consist of $\mathrm{pH}$ test, dissolved oxygen test (DO), biochemical oxygen demand test (BOD), nitrate test, phosphate test, salinity test, and temperature to support the existence of coliform and determine the water quality. The results from the analysis determine how testing and monitoring should proceed in the future when addressing the Galveston Bay water quality.

\section{Methodology}

Water samples collected were analyzed using the LaMotte's Earth Force ${ }^{\varpi}$ Estuary and Marine Monitoring Kit. This particular kit was selected to analyze brackish waters of the Galveston Bay using colorimetric methods that are nonhazardous to the environment. The kit consists of coliform bacteria, dissolved oxygen, biochemical oxygen demand, nitrate, $\mathrm{pH}$, phosphate, salinity, and temperature tests. The equipment and apparatuses needed to carry out each test were included in the water monitoring kit.

The primary interest of this study is to determine the presence of coliform in the Galveston Bay. However, other properties of water were obtained to learn how each contributes to the possible presence of coliform in water. The water samples were collected on November 25, 2015 from three separate recreational beaches of the Galveston Bay in Texas. The first site was Seawall Beach $\left(29^{\circ} 16^{\prime} 18.6024^{\prime \prime} \mathrm{N}, 94^{\circ} 48^{\prime} 56.8692^{\prime \prime} \mathrm{W}\right)$, the second site was Stewart Beach $\left(29^{\circ} 18^{\prime} 18.7596^{\prime \prime} \mathrm{N}, 94^{\circ} 46^{\prime} 3.2016^{\prime \prime W}\right)$, and the third site was East Beach $\left(29^{\circ} 19^{\prime} 8.4288^{\prime \prime} \mathrm{N}, 94^{\circ} 44^{\prime} 45.3336^{\prime \prime}\right)$. Each site location is placed on Google Map in Figure 1. These water samples were collected from each respective beach at waist-deep levels described in protocols provided in the kit. The three samples from each site were collected in separate sterile wide mouth container with a screw cap. The Dissolved Oxygen and Biochemical Oxygen Demand were tested immediately. The other tests were completed within the hour.

\subsection{Coliform Bacteria}

The coliform bacteria test was performed by placing a coliform tablet in vial where water was added to the $10-\mathrm{mL}$ calibration mark. The vial was capped and then stored for incubation without disturbing in an upright position, at room temperature and out of direct sunlight for 48 hours. The results from the colorimetric response were determined by specifications indicated inmanualfor coliform levels at above or below 20 $\mathrm{cfu} / 100 \mathrm{~mL}$. The presence of coliform indicates fecal contamination in the water.

\subsection{Dissolved Oxygen}

The testing of percent oxygen saturation using the Dissolved Oxygen (DO) test was conducted to determine the health of aquatic ecosystems such as the Galveston Bay. After recording the water temperature, the test tube was submerged in the sample and filled completely to the top. The DO TesTabs ${ }^{\circledast}$ in the quantity of two were added and capped tightly to eliminate the air. The contents of the tube were inverted several times until the tablets were dissolved. The tubes were allowed to sit for five minutes for the 


\section{Galveston Bay Water Analysis Sites}

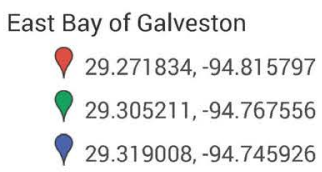

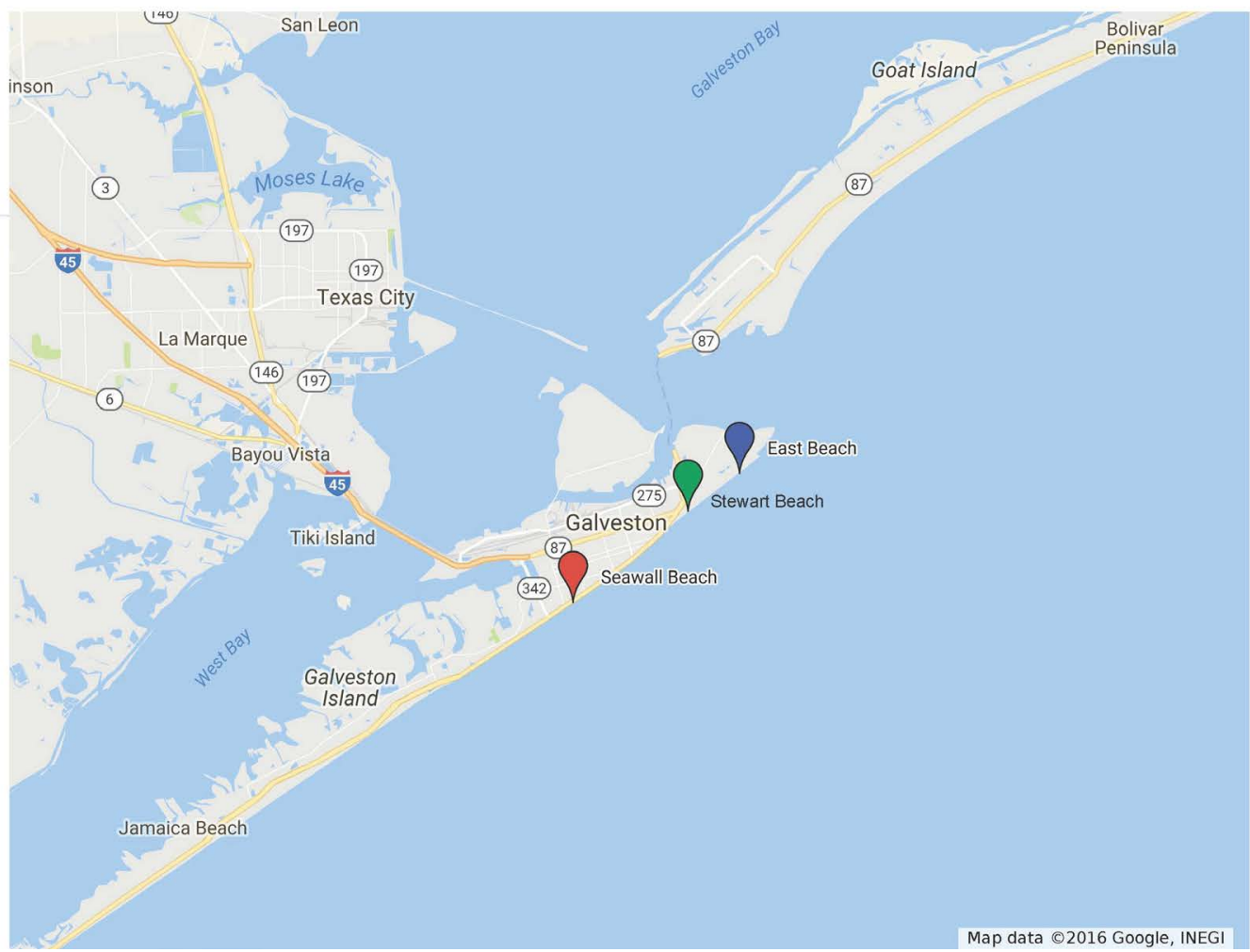

Figure 1. Map of the three water analysis sites near Galveston's recreational beaches.

color to develop and then compared to the color chart provided in manual.

\subsection{Biochemical Oxygen Demand (BOD)}

This test measures the quantity of dissolved oxygen used bacteria which robs other aquatic organisms of dissolved oxygen needed for survival. The BOD was measured by submerging a small test tube into the water sample and then sealing the tube. The tube was subsequently covered using aluminum foil and stored in a low light environment for 5 days at room temperature. After incubation, the tube was unwrapped and two Dissolved Oxygen TesTabs ${ }^{\circledR}$ were added. The tubes were sealed carefully using screw capsto ensure no air bubbles and inverted several times until the tablets were dissolved. After the tube sat for five minutes, it was analyzed by comparing to the BOD color chart provided in the kit.

\subsection{Nitrate}

To measure excess nitrate in water samples, the test tube was filled to its 5 - $\mathrm{mL}$ calibration mark. A Nitrate Wide Range CTA TesTab ${ }^{\circledR}$ was added to the test tube. The tube was capped and placed into a protective sleeve. The tube was mixed for two minutes to disintegrate the tablet and then incubated for 5 minutes for the red color to develop. The response was compared to the Nitrate Color Comparison Chart in the manual. 


\subsection{PH}

The acidity of water is determined using the colorimetric $\mathrm{pH}$ response. The measurement was performed by filling the test tube to $10-\mathrm{mL}$ calibrated mark with sample and then adding one $\mathrm{pH}$ Wide Range TesTab ${ }^{\oplus}$. The tube was capped, then mixed by inverting until the tablet was dissolved. The test tube color response was immediately compared to the $\mathrm{pH}$ color chart provided in manual.

\subsection{Phosphate}

Excess phosphate may indicate an increase in bacterial activity and decrease dissolved oxygen levels. The phosphate test was conducted by filling the test tube to the $10-\mathrm{mL}$ water mark and adding one phosphorus TesTab ${ }^{\circ}$. The tube was capped and mixed by inverting repeatedly until the tablet was dissolved. The sample sat for five minutes to incubate in which a blue color was formed. The blue color from the sample was compared to the phosphate color chart.

\subsection{Salinity}

The Salinity test was performed by pipetting 5 drops of water into the round tube and filling the tube to the $100-\mathrm{mL}$ mark with distilled water. A test tube was subsequently filled with $10-\mathrm{mL}$ of the diluted sample in which one Chloride $\mathrm{TesTab}^{\oplus}$ was added. The test tube was capped and gently mixed until dissolved. The tube was then placed next to the salinity color chart for results. This test indicates the approximate quantity of all salts dissolved in water that affects aquatic life.

\subsection{Temperature}

Temperature changes in the water are linked to the presence of dissolved oxygen. The temperature of the water was taken by placing a thermometer strip four inches below the surface of the beach water for one minute after which the temperature was recorded.

The methods and results were carried out as describe in kit to determine the quality of water along the East Bay of the Galveston Bay. This study reflects only one day of analyses. These results were compared to results obtained by other monitoring groups of the Galveston Bay during the same month of analysis.

\section{Results}

In Table 1, the data represent the analysis of water from three separate areas of the Galveston Bay area near the recreational beach sites viewing the Gulf of Mexico. The presence of coliform bacteria in each specific beach resulted in a positive response. Other test and properties of water support these findings in regards to the presence of coliform. High levels of phosphate were found which can contribute to increased bacterial activity such as coliform. The dissolved oxygen level at the Stewart Beach was 4 ppm unlike the levels at the Seawall and East Beaches which had a higher level of oxygen of $8 \mathrm{ppm}$. However, dissolved oxygen consumed by the bacteria was between 4 
Table 1. Analysis of water samples at sea wall beach, Stewart beach, and east beach on the east side of Galveston bay on November 25, 2015.

\begin{tabular}{cccc}
\hline & Seawall $^{*}($ Beach 1) & Stewart (Beach 2) & East (Beach 3) \\
\hline Water Temperature $\left({ }^{\circ} \mathrm{C}\right)$ & 22 & 17 & 22 \\
Dissolved $\mathrm{O}_{2}(\mathrm{ppm})$ & 8 & 4 & 8 \\
Percent Saturation of $\mathrm{O}_{2}$ & 76.0 & 34.5 & 76.0 \\
Nitrate $(\mathrm{ppm})$ & 5 & 5 & 5 \\
$\mathrm{pH}$ & 7 & 8 & 7 \\
Phosphate $(\mathrm{ppm})$ & 1.0 & 1.0 & 0.5 \\
Salinity $(\mathrm{ppt})$ & 35 & 35 & 35 \\
Coliform Bacteria $>20 \mathrm{cfu} / 100 \mathrm{~mL}$ & Positive & Positive & Positive \\
Biochemical $\mathrm{O}_{2}$ Demand & 4 & 8 & 8 \\
\hline
\end{tabular}

*Across from San Luis Resort.

ppm at the Stewart beach and $8 \mathrm{ppm}$ at the other sites based on the biochemical oxygen demand levels at each site. The results suggest that bacteria more than likely consumed more dissolved oxygen than other aquatic organisms. However, there are some discrepancies when evaluating the differences between dissolved oxygen and BOD at the Stewart site. The other parameters in Table 1 represented ideal conditions for the water in the Galveston Bay. The other observations noted do not necessarily suggest a direct link to the presence of coliform.

\section{Discussion}

The presence of coliform in the water at the three sites was confirmed by a positive colorimetric response of gold-like color. Other tests such as the dissolved oxygen and biochemical oxygen demand support the coliform findings at all three sites in the Galveston Bay. The saturation of dissolved oxygen was $34.5 \%$ at the Stewart site where the other sites where the same at $76.0 \%$. A lower percent of dissolved oxygen eludes to a high presence of bacteria which is more likely from sewage pollution in the Galveston Bay. The BOD in Table 1 represents the consumption of dissolved oxygen by bacteria at each site. There is a discrepancy with the data at the Stewart site when taking the difference of the results between the dissolved oxygen and BOD. This discrepancy shows a difference of $4 \mathrm{ppm}$ which can only be $0 \mathrm{ppm}$ or higher. Although, there is a negative deviation with the two test results, it does not negate presence of coliform at the Stewart site. The actual fecal coliform bacteria per 100 milliliter water are not determined; however, the positive response does indicate that each site contains more than 20 coliform $\mathrm{cfu} / 100 \mathrm{~mL}$. Two other properties that may contribute to the presence of coliform are the temperature and excess phosphate. Usually, higher water temperatures can decrease the levels of dissolved oxygen in a body of water causing bacteria such as coliform to thrive more and living organisms to reduce in size and appearance. Temperatures at the Seawall and East Bay were both at $22^{\circ} \mathrm{C}$. The temperature at the Stewart site 
was $17^{\circ} \mathrm{C}$. These temperatures obtained from the three sites were used to determine the percentsaturation of dissolved oxygen. None of the sites had $100 \%$ saturation of dissolved oxygen, thus coliform is likely at each site with a population over $20 \mathrm{cfu} / 100 \mathrm{~mL}$ of water. An excessof phosphate can lead to an increase in coliform activity due to fecal matter from human or animal waste, runoffs and industrial pollution. The Galveston Bay is exposed to all three factors which contributes to the pollution of water and is susceptible to an increase in coliform population. The results in Table 1 indicate the phosphate level of $1 \mathrm{ppm}$ or less are considered to be normal. Thus, the presence of coliform was likely not attributed to the phosphate. The presence of nitrate at each site is $5 \mathrm{ppm}$. The nitrate at this level does not lead to an increase in bacterial activity. Therefore, DO, BOD and percent saturation of oxygen results provide additional evidence of coliform in the East Bay of Galveston's beaches. The $\mathrm{pH}$ and salinity results address other aspects of water quality.

The monitoring sites selected for this investigation was along the East side of Galveston towards the Gulf of Mexico. Other monitoring groups conducted analysis along the East side but did not conduct testing for fecal matter. Therefore, observations in Table 1 were compared to other nearby sites that were located along or within the Galveston island as seen in Figure 2. The monitoring sites in Table 2 were reported by

\section{Galveston Bay Water Analysis Sites}

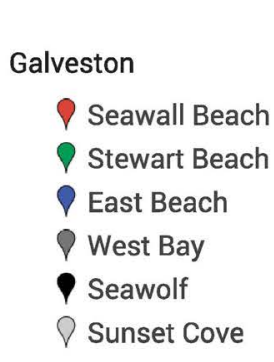

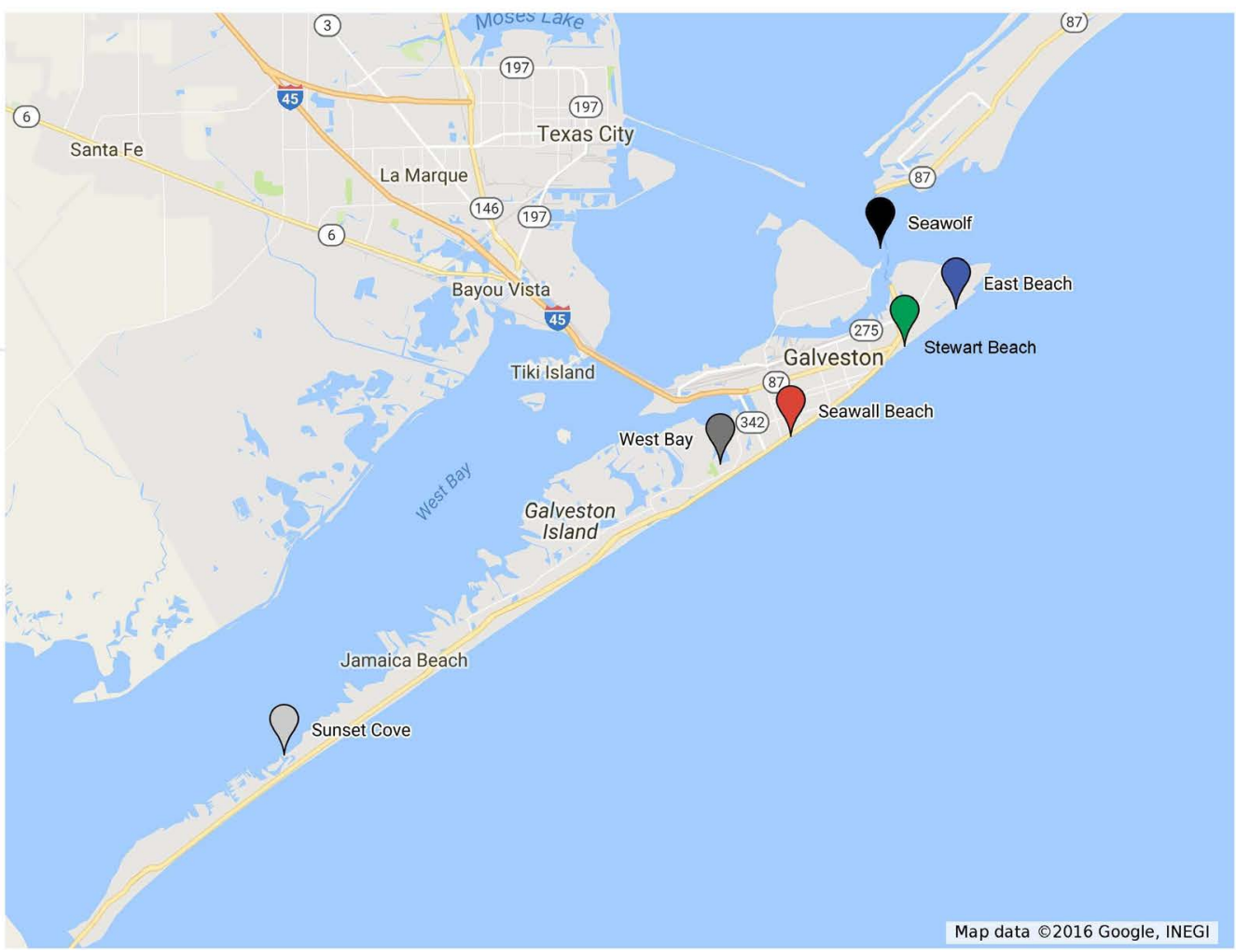

Figure 2. A map of monitoring sites near Galveston's recreational beaches. 
Table 2. Water analysis near Seawolf Park sunset cove and West Bay.

\begin{tabular}{|c|c|c|c|}
\hline & Seawolf Park ${ }^{\mathrm{a}}$ & Sunset Cove $\mathrm{e}^{\mathrm{a}}$ & West Bay \\
\hline Date & $11 / 28 / 2015$ & $11 / 15 / 2015$ & $10 / 8 / 2015$ \\
\hline Water Temperature $\left(\mathrm{C}^{\circ}\right)$ & 18 & 16 & 27.1 \\
\hline Dissolved Oxygen (ppm) & 7.8 & 5.8 & 4.8 \\
\hline $\mathrm{pH}$ & 8.0 & 7.6 & 8.1 \\
\hline Salinity & $16.1 \mathrm{ppt}$ & $20.0 \mathrm{ppt}$ & $22.6 \mathrm{ppm}^{*}$ \\
\hline Enterococcus (mpn/100 mL) & - & 1 & 5 \\
\hline Ammonia-N (ppm) & - & - & 0.3 \\
\hline Kjeldahl Nitrogen (ppm) & - & - & 0.7 \\
\hline Nitrate-N (ppm) & - & - & 0.02 \\
\hline Phosphorus (ppm) & - & - & 0.12 \\
\hline
\end{tabular}

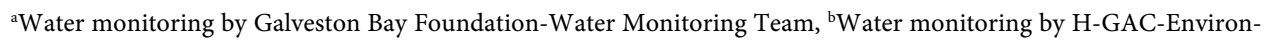
mental Institute of Houston, ${ }^{*}$ The reported units in ppm may be a misprint, test not performed.

Galveston Bay Foundation and Houston-Galveston Area Council (H-GAC) [10] [11]. The Sea wolf Park and Sunset Cove monitoring in Table 2 were obtained in November 2016 demonstrating similarities to data obtained for the three East Bay sites on November 25, 2016 with exception to salinity [12]. The nitrate, phosphate and coliform test were not recorded. The Sunset Cove site utilized the enterococcus indicator rather than coliformin dicator. The level of enterococcus at Sunset Cove is $1 \mathrm{mpn}$ (most probable number) $/ 100 \mathrm{~mL}$. The West Bay site monitored in October 2015 is located within the island giving a higher temperature at $27.1^{\circ} \mathrm{C}$ when comparing to East Bay, Seawolfg Park and Sunset Cove [10] [11]. A higher temperature as recorded for West Bay can indicate that there is less dissolved oxygen in the water which could lead to the presence of coliform bacteria. The bacterial activity of enterococcus was $5 \mathrm{mpn} / 100 \mathrm{~mL}$ at the West Bay monitoring site which was higher than Sunset Cove (see Table 2). Both assessments appear to be within the criterion range for quality water. However, the EPA and TCEQ based the criterion mainly on colony forming units (cfu) rather thanmost probable number ( $\mathrm{mpn}$ ) to determine the limitations of recreational use of water based on enterococci results. The 2012 recreational water quality criteria for enterococci released by the EPA suggest that the upper limit of enterococci is at $35 \mathrm{cfu} / 100 \mathrm{~mL}$ using geometric mean and $130 \mathrm{cfu} / 100 \mathrm{~mL}$ using the statistical threshold value at a rate of 36 per 1000 illnesses [13]. The Texas Commission on Environmental Quality (TCE Q) adopted the same limits as the EPA [14] [15]. The East Bay results in Table 1 suggest that the coliform is above $20 \mathrm{cfu} / 100 \mathrm{~mL}$; however, its actual level is not known. The results in Table 1 and Table 2 indicate the presence of coliform activity in the Galveston Bay Recreational area, respectively. However, testing of the presence of enterococcus is needed to fully assess the East Bay sites as well as other sites on a continuous basis. The limitations to this study are incomplete analyses of water at each site for nitrate, phosphate and enterococcus levels. Although, enterococcus is the preferred 
methodto determinefecal contamination in regards to human risk, the total coliform test and fecal coliform should be obtained for further analysis. Methods for enterococci should be prepared according to EPA standards and its outcomes need to be based on EPA limits of $35 \mathrm{cfu} / 100 \mathrm{~mL}$ [14].

\section{Conclusion}

The East bay water monitoring sites demonstrate coliform bacteria activity based on positive coliform results. The $\mathrm{DO}, \mathrm{BOD}$ and percent saturation of oxygen results contributed to the evidence of coliformas well. Other monitoring groups analyzed enterococci which is a subgroup within the fecal streptococcus group along the West Bay of Galveston. The presence of enterococci at $1 \mathrm{mpn} / 100 \mathrm{~mL}$ and $5 \mathrm{mpn} / 100 \mathrm{~mL}$ does indicate the presence of fecal matter but it likely below the EPA limits indicating that the water is safe for recreational uses. There is some concern that fecal matter is present in water, since the recommended methods for enterococci of EPA and adopted by TCEQ are not applied to verify that the water quality at the Sunset Cove and West Bay sites is below the limits and safe recreational use. Further monitoring is needed to determine the levels of coliform, fecal coliform and enterococci at each of the East Bay sites to determine how these studies may correlate in determining water quality of the Galveston Bay near each recreational beach site and the approach to test for fecal matter [16]. By monitoring each pathogen, it will assist in determining the origin of fecal matter [17]. If these results are greater than EPA requirements, monthly water monitoring of fecal coliform and enterococci is necessary to further address how fecal coliform activity occurs along the East bay of Galveston bay.

\section{References}

[1] Guillen, D. (2015) Galveston Waters Test High for Fecal Bacteria. Houston Chron. http://www.chron.com/neighborhood/bayarea/health/article/Galveston-waters-test-high-fo r-fecal-bacteria-6346435.php

[2] Bennett, A. (2015) Fecal Bacteria High at Texas Beaches Following Flooding. KHOU, Houston.

[3] Rice, H. (2015) Storm Forces 750,000 Gallons of Sewage into Galveston Bayou. Houston Chron.

http://www.chron.com/neighborhood/bayarea/article/Galveston-dumps-75-000-gallons-ofpartially-6480597.php

[4] Al-Bahry, S.N., Mahmoud, I.Y. and Al-Musharafi, S.K. (2012) Antibiotic Resistant Bacteria Used as Bioindicators of Environmental Pollution Produced by Tertiary Treated Sewage Effluent. 11 th International Conference on Modelling, Monitoring and Management of Water Pollution. WIT Transactions on Ecology and the Environment, 164, 313-321.

[5] Center for Disease Control and Prevention, American Water Works Association (2013) Frequently Asked Questions About Groundwater Rule Advisories. http://www.cdc.gov/healthywater/emergency/dwa-comm-toolbox/tools-templates-main.ht $\underline{\mathrm{ml}}$

[6] Lester, J., Gonzalez, L., Gallaway, A., Anderson, J.B. and Weeks, P. (2010) State of the Bay: A Characterization of the Galveston Bay Ecosystem. 3rd Edition, Galveston Bay Estuary 
Program-Texas Commission on Environmental Quality, The Woodlands.

http://galvbaydata.org/Portals/2/StateOfTheBay/2011/Chapters/ii\%20Executive\%20Summa ry.pdf

[7] US EPA (1976) Recreational Water Quality Criteria. U.S. Environmental Protection Agency, Washington DC.

[8] Mote, B.L., Turner, J.W. and Lipp, E.K. (2012) Persistence and Growth of the Fecal Indicator Bacteria Enterococci in Detritus and Natural Estuarine Plankton Communities. Applied and Environmental Microbiology, 78, 2569-2577. http://dx.doi.org/10.1128/AEM.06902-11

[9] Hlavsa, M.C., Roberts, V.A., Kahler, A.M., Hilborn, E.D., Wade, T.J., Backer, L.C. and Yoder, J.S. (2014) Recreational Water-Associated Disease Outbreaks-United States, 2002010. Morbidity and Mortality Weekly Report, 63, 6-10.

[10] Galveston Bay Foundation. (n.d.) Human Health Effects Index. Retrieved from H-GAC's Water Resources Information Map (WRIM). http://gulfcitizenscience.org/

[11] Houston-Galveston Area Council (n.d.) Monitoring Stations. Retrieved from H-GAC's Water Resources Information Map (WRIM).

http://h-gac.maps.arcgis.com/apps/MapSeries/index.html?appid=30b802d67f5d4a2aa7915c c30bca9318

[12] GCOOS Integrated Water Quality Network (n.d.) Galveston Bay Foundation Monitoring Points. Retrieved from Citizen Science. http://gulfcitizenscience.org/gbf db

[13] OFFICE OF WATER 820-F-12-058. (2012) Recreational Water Quality Criteria. US EPA.

[14] US EPA 2002a (2002) Method 1600: Enterococci in Water by Membrane Filtration Using Membrane-Enterococcus Indoxyl- $\beta$-D-Glucoside Agar (mEI).

http://www.epa.gov/microbes/1600sp02.pdf

[15] Texas Commission on Environmental Quality (2007) Chapter 307-Texas Surface Water Quality Standards.

https://www.tceq.texas.gov/assets/public/waterquality/standards/TSWQS2010/TSWQS2010 rule.pdf

[16] Davies, C.M., Long, J.A. and Ashbolt, N.J. (1995) Survival of Fecal Microorganisms in Marine and Freshwater Sediments. Applied and Environmental Microbiology, 61, 1888-1896.

[17] Savichtcheva, O. and Okabe, S. (2006) Alternative Indicators of Fecal Pollution: Relations with Pathogens and Conventional Indicators, Current Methodologies for Direct Pathogen Monitoring and Future Application Perspectives. (Elsevier, Ed.) Water Research, 40, 24632476.

\section{Appendix}

Table A. Fecal coliform bacteria per 100 milliliters of water.

\begin{tabular}{ccc}
\hline Desirable & Permissible & Water use \\
\hline 0 & 0 & Potable and well water (for drinking) \\
$<200$ & $<1000$ & Primary Contact (for swimming) \\
$<1000$ & $<5000$ & Secondary contact (for boating \& fishing) \\
\hline
\end{tabular}


Submit or recommend next manuscript to SCIRP and we will provide best service for you:

Accepting pre-submission inquiries through Email, Facebook, LinkedIn, Twitter, etc. A wide selection of journals (inclusive of 9 subjects, more than 200 journals)

Providing 24-hour high-quality service

User-friendly online submission system

Fair and swift peer-review system

Efficient typesetting and proofreading procedure

Display of the result of downloads and visits, as well as the number of cited articles

Maximum dissemination of your research work

Submit your manuscript at: http://papersubmission.scirp.org/

Or contact ojms@scirp.org 